\title{
MINERAIS PESADOS DOS SEDIMENTOS QUATERNÁRIOS DO LITORAL SUL PAULISTA
}

\author{
A.M.Coimbra ${ }^{1}$ \\ M.G.Tessler ${ }^{2}$
}

No Estado de São Paulo a planície costeira, a sul da foz do Rio Ribeira de Iguape, tem a forma de um vasto crescente de $130 \times 40 \mathrm{~km}$, cobrindo superfície de aproximadamente 2500 $\mathrm{km}^{2}$. Seus limites, a SW e NE, são compostos por pontões do embasamento que alcançam o oceano.

O embasamento, à retaguarda da planície, é predominantemente metamórfico, com presença de filitos, micaxistos, migmatitos, gnaisses, quartzitos, anfibolitos e calcoxistos, com intrusões de granitos, adamelitos e granodioritos. Cortando esse complexo, afloram diabásios e rochas alcalinas intrusivas.

Para a separação dos minerais foram considerados os intervalos areia fina e muito fina de 120 amostras de afloramentos de cordões litorâneos pleistocênicos (Fm. Cananéia), 10 amostras de cristas praiais holocênicas, 47 amostras da região intermarés e 133 amostras da superfície de fundo da plataforma sul paulista.

Após a separação em bromofórmio, o resíduo pesado foi submetido a separação eletrostátiça, precedida de separação com imã manual, em Franz ajustado para campos de 0,3 e 0,5 A. Cada subamostra foi analisada em. lâminas de montagens não permanentes em líquido com índice de refração de 1,547 .

Devido à presença de grande quantidade de minerais opacos foram contados pelo menos cem grãos de minerais transparentes não micáceos. A maturidade mineralógica foi definida com base no número de espécies mineralógicas (soma dos minerais com freqüência maior que 1\%) e pelo índice ZTR (somatória das freqüências relativas dos minerais ultraestáveis zircão, turmalina e

\footnotetext{
${ }_{1}^{1}$ Departamento de Paleontologia e Estratigrafia, Instituto de Geociências, USP.

${ }^{2}$ Instituto de Oceanografia, USP.
} 
rutilo).

Os resultados obtidos não evidenciam diferenças marcantes nas assembléias dos sedimentos pleistocênicos e holocênicos das áreas emersas e marinha. Ambas as frações (areia fina e muito fina) apresentam baixa diversidade mineralógica, pois o conjunto de dez minerais mais freqüentes (ordenados por ordem alfabética: andaluzita, cianita, epidoto, estaurolita, granada, hornblenda, rutilo, sillimanita, turmalina e zircão) é responsável por mais de $95 \%$ do concentrado pesado transparente, para todas as unidades estudadas.

No litoral paulista têm sido consideradas duas fontes de suprimento de minerais pesados para os sedimentos da região praial; o Complexo Serrano e os sedimentos da plataforma continental interna. Analisando-se as prováveis proveniências do conjunto de minerais originários do Complexo Serrano verifica-se que turmalinas prismáticas com inclusões, estaurolitas, cianitas, sillimanitas, granadas e andaluzitas indicam origem ligada a rochas de médio a alto grau de metamorfismo.

A grande concentração de estaurolitas e granadas próximo a foz do Rio Ribeira de Iguape, sugere ser a drenagem atual a fornecedora desses minerais, provenientes de gnaisses e migmatitos homogêneos. O rutilo, proveniente de metamórficas de alto grau onde este mineral é abundante e ainda de migmatitos, também seria carreado para a região costeira pelos rios de serra que desaguam nos canais lagunares e na bacia do Ribeira.

A abundância de hornblenda indica como fonte paleossomas anfibolíticos do complexo migmatítico, enquanto que sua associação com hiperstênio, em especial nos sedimentos pleistocênicos da planície costeira, sugere contribuição de granulitos, mais especificanente chamoquitos.

Turmalinas com crescimento secundário e zircão redondo róseo, indicam que rochas metamórficas (metassedimentos) de baixo grau (fácies xisto verde) atuaram como fonte em épocas pretéritas.

A segunda fonte, qual sejam os sedimentos reliquiares da plataforma, é representada pelas grandes porcentagens de grãos arredondados de zircões e turmalinas.

A perowskita, detectada ao longo de toda a faixa costeira sul, com formas subarredondadas e arredondadas, que se assemelham às características deste mineral nas praias do litoral paranaense, indicaria transporte ao longo da costa, reforçando idéia da existência de sedimentos preexistentes como fonte.

O índice ZTR decresce dos sedimentos pleistocênicos para os mais recentes, evidenciando a existência de retrabalhamento de sedimentos nos eventos deposicionais sucessivos 
das formações quaternárias. A ausência de minerais autigênicos e de alterações significativas na estrutura e forma (dissolução, crescimento secundário, etc.), demonstram pouca importância dos fenômenos diagenéticos nesses sedimentos tão recentes.

Durante todo o ciclo erosivo/deposicional quaternário atuante no litoral sul paulista, o Complexo Serrano bem como a superfície de fundo da plataforma interna, vêm suprindo de sedimentos a região praial. A influência destas fontes manteve-se praticamente constante ao longo do tempo geológico, oscilando, suas importâncias relativas, em função da efetividade de ação dos sistemas fluviais em oposição ao sistema marinho, durante os eventos de oscilação do nivel do mar no Quaternário. 